\title{
Influence of Strategic Resourcing as Strategic Position on the Performance of Manufacturing Companies in Kenya, A Case of Textile and Apparel Companies in Kenya
}

\author{
Dr. Gitahi Njenga \\ School of Business and Economics, Kabarak University, 13 P.O. Box Private Bag, Kabarak, 20157, Kenya \\ Dr. Maina Waiganjo \\ School of Business and Economics, Kabarak University, 13 P.O. Box Private Bag, Kabarak, 20157, Kenya \\ Ombati Maryanne Kerubo \\ Kabarak University, 13 P.O. Box Private Bag, Kabarak, 20157, Kenya
}

\begin{abstract}
This study sought to explore the influence of strategic positioning on the performance of manufacturing companies in Kenya, taking a case of textile and apparel companies in Kenya. The study employed descriptive research design targeting 63 companies in textile and apparel manufacturing sub sector. Data was collected targeting the senior managers/operation managers in the selected firm using a questionnaire. Email method was used to distribute the questionnaires. The data collected was analyzed in SPSS and presented using charts and tables. Data collected was crosschecked for completeness before entering in SPSS for analysis. Both descriptive and inferential statistics. The study found strategic resourcing, research and development, and marketing strategies had statistically significant effect on the performance of apparel and textile firms in Kenya. The study concludes that strategic positioning is an effective approach in sustaining the performance of manufacturing firms in Kenya.
\end{abstract}

Keywords: Strategic positioning, Strategic resourcing, Performance

DOI: $10.7176 / \mathrm{EJBM} / 12-30-06$

Publication date:October $31^{\text {st }} 2020$

\section{Introduction}

\subsection{Background of study}

Strategic decisions have long-term implications and are often permanent. Within the manufacturing industry, an important strategic decision is about defining those functions (production, supply and service) that an organization must perform internally and those that should remain external. This is often referred to as strategic decision-making and is concerned with the quality and direction of vertical integration techniques and links relationships with suppliers, distributors and customers (Lii \& Kuo, 2016). Such a position is directly affected by the actions associated with the dismissal of employees, sales, partnerships, comparisons with purchases, etc., so it should be a priority for many manufacturers.

Traditionally, actions to improve the competitiveness of manufacturing operations tend to focus on those manufacturing activities that reside within the four walls of the factory. Manufacturing professionals are concerned with efforts such as technology investment, reduced production process, production planning and manufacturing / purchasing strategies. Often these respond to pressures to reduce operating costs or improve service delivery. Today, however, there is a growing awareness of the practicality of the production process and, as a result, the concepts and methods used in manufacturing are changing.

The idea of strategic planning is another example of taking a more holistic view of production activities. In this context, strategic planning refers to the decision-making process for selecting those production-related products to be performed internally, as well as those outside and under the ownership and control of suppliers, partners, distributors and customers (Mackelprang, Bernardes, Burke and Welsh, 2018). The strategic nature itself can be thought of as a stepping stone or 'competitive environment' that the organization accepts within a network of supply chain operations.

Strategic planning requires more complex business operations, and managing this complexity escalates further, and requires basic management strategies, tools and knowledge (Rajkumar \& Abraham, 2018). Businesses have used a variety of methods in an effort to position themselves in the global market. This includes; research and development (Bai \& Liu, 2019), product segregation (Hill et al., 2001), cost leadership (Valipour, Birjandi and Honarbakhsh, 2012), marketing strategy (Luo, 2017), multi-product line strategy (Onguko and Ragui, 2014), resource strategy (Onguko \& Ragui, 2014) among others. However, this study will focus on the provision of strategies for resourcing and strategies for strategic planning.

Strategic resourcing is one of approaches that organisation may use to attain a strategic position in the market. Strategic resourcing focus on financial resources, technology, working capital, skills and networks. According to 
Sieger and Minola, (2017), financial instruments are the money available in the business of using cash, liquid securities and credit lines. Noreen, (2015) also argues that corporate executives must have sufficient skills and expertise to track financial resources and apply them to profitable programs. Huselid, et al,(2015) also argue that a product or service may be technically and technologically advanced, but it requires a personal contribution.

Manufacturing industries play a vital role in economic growth and development. Manufacturing provides an important source of demand for goods and services in other sectors of the economy, and this trade in other industries is not limited to the steps of the GDP manufacturing sector but is calculated on the overall scale of its total production. According to the latest figures, production contributes $£ 6.7$ trillion to the global economy (Suleiman, 2016). The manufacturing sector employed 12.4 million workers in 2015 or about 8.8 percent of U.S. jobs. (Sueliman, 2016) Manufacturing industries generated \$ 2.1 trillion in GDP (12.5 percent of U.S. total domestic production) in 2013. In the United Kingdom, manufacturing accounts for $10 \%$ of GVA and $45 \%$ of exports to the UK and directly employs 2.7 million people (Merozwa, 2015).

In Kenya, the real value of the manufacturing sector increased by 4.2 per cent in 2018 compared to the revised growth of 0.5 per cent in 2017. This growth is due to increased production of dairy products, tea, coffee and sugar due to the favourable climate. The decline in production was recorded in the small sectors involved in the manufacture of plastics, wood and other wood products, and other non-metallic mineral products (Kenya Association of Manufacturers [KAM], 2018).

The manufacturing industry plays a major role in Kenya's economy. It has generated an average of $8.9 \%$ of Kenya's total wealth over Kenya since 2014 (KNBS, 2019). In 2018, Export Processing Zone sold KSh 77.2 billion worth of exports. In addition to sales made in foreign markets, the manufacturing sector has a significant impact on other industries such as the service industry. It is also under President Kenyatta a major sector of change and part of Kenya's 2030 vision. However, Kenya's manufacturing industry has been declining in contributing to the country's GDP for the past five years in 2017 reporting poor performance on the industry's contribution to GDP (KAM, 2018).

The textile and clothing sector in Kenya is facing a difficult business environment, low productivity and noncompliance with the delivery and demand for skills of workers, difficulty in maintaining and improving technology and equipment, delivery of adequate quality materials; it is associated with higher input costs, increased demand challenges and access to domestic and international markets (GOK, 2018). However, little is known about the strategic position of Kenyan manufacturing companies. Kenya's manufacturing sector faces the challenges of China's cheap products. According to a study by the Kenya Association of Manufacturers (2018), 63\% of manufacturers cited the influx of cheap products from China as the biggest problem encountered in 2018. Cotton Africa, (2016) argued that the textile and textile companies in Kenya face a severe competition in $t$ from the importation of second-hand clothes at the lowest prices in selected stores and street vendors which is why the textile and textile industry is weakening. The World Economic Forum also explains that Kenya's clothing and textile industry is facing challenges including expensive electricity, high wages and outdates machinery, resulting in poor production capacity or expensive products compared to imported goods.

This means that the key challenge for Kenyan producers lies in defining their strategic position among companies in the global producer markets that must be in line with the organizational structure. Increasingly, these challenges cannot effectively address the fragmentary changes in certain organizational structures, but rather rely on associations and interdependence between different factors in the manufacturing and business environment, and those that cannot do so face the risk of market losses. The competitive advantage of a company is largely dependent on the strength of the business environment in which it participates, and each company has its own 'position' with its own strategy, selection of internal and external functions owned by the organization, and controls on it. It is for this reason that this study sought to examine the impact of strategic positioning on the performance of Kenyan manufacturing companies, textile and clothing companies in Kenya.

\subsection{Objectives}

The study sought to assess the influence of strategic resourcing on the performance of the textile and apparel manufacturing companies in Kenya

\subsection{Justification of the Study}

Promoting Kenyan manufacturing companies is very crucial in not only ensuring continued economic growth but also reliable supply to its citizen. Citing the current china coronavirus epidemic, a country that entirely relies imported products from China is likely to be adversely affected. Consequently, manufacturing sector contribute widely to other industries such as service industries. For instance, food and beverage sub sector which account of $43 \%$ in manufacturing sector is largely relied up by nearly all other sectors in the country. It is worth to note that, apparel and textile industry employs most of person in Kenya. EZP companies alone employ approximately 1,800 workers per company and additional over 74,000 small and micro companies (KNBS, 2015; GoK, 2015). Therefore, effort should be made to ensure effective performance of manufacturing sector to sustain the economic 
growth.

The study may largely benefit the management team of manufacturing companies in Kenya. The management may be in a position to comprehend the value of strategic positioning on the performance of manufacturing companies. The policy makers may use the insight from this study to influence the learning through manufacturing academy under Kenya Association of Manufacturers. Academicians and scholars may benefit from the study as they may be in a position to advance the critique of existing knowledge and provide improvements. The study also highlights gaps that could infer future studies on the subject.

\section{Literature Review}

\subsection{Strategic resourcing and the performance}

Many strategies are used by organizations in an effort to show off their effectiveness. For example, the integration of several organizations facilitates product market penetration (Porter, 2017). The partnership between the organization creates an opportunity to share resources and firms while working with partners to develop additional resources and skills as a function of new competitive advantages. Combining technology and skills from various organizations improves product performance. In addition, the integration of financial resources and strategic collaboration helps to improve product performance. Strategic resources, however, are often invisible, are not easily identified and do not develop rapidly (Phillips, 2017; Onguko and Ragui, 2014).

According to Sieger and Minola, (2017), financial instruments are the money available in the business of using cash, liquid securities and credit lines. Before entering a business, an entrepreneur needs to obtain adequate financial resources in order to be effective and efficient in order to promote success. Managers may tend to assume that their problems can be solved as long as they have more money to spend. In addition, having more money to spend is better than having very little. However, large sums of money may not always have the same effect if money is not well managed. There may be little link between the quality of the delivery system and the organization's financial management system. Working organizations often know how their money is spent (Junqueira, 2016).

Noreen, (2015) argues that corporate executives must have sufficient skills and expertise to track financial resources and apply them to profitable programs. The task of managing is planning, organizing, staffing, leading, and controlling. All of these activities are heavily influenced by the amount of money available. Managers and program staff can simply perform their assigned tasks without understanding their financial problems. Managers need to have certain ways of knowing what is going on with regard to their financial resources if they are going to make informed management decisions. This work is done by installing and managing the accounting system. That program can be automated at some point, but the book program will be very helpful in the beginning. However, no matter how the reports are produced and how the records are kept, they must be accurate and produced in a timely manner so that employees can make their decisions on good information.

The job of the company's management is to hire, train and ultimately motivate them to achieve their goal. It involves resolving a problem that arises between employees. The Department of Labor is working with employees and their problems. The production of any product or service and the smooth operation of an organization cannot be done alone in the capital. Another great need is human labor. A product or service may be technically and technologically advanced, but it requires a personal contribution. A major influence factor is the operational capacity of any type of production (Huselid, et al, 2015).

Organizations need different types of staff. Some organizations manage their subordinates or employees in the same way they treat their superior staff but each group is hired separately and selected on different terms. They come in different training programs and are paid separately. If a company is focused on customer service then it will need to build customer performance skills and behavior in all customer-focused jobs, but your specific strategy for hiring, selection, training and rewards for various positions (Schake \& Craft, 2019).

\subsection{Conceptual framework}

According to Adom, Hussein and Agyem, (2018) a conceptual framework describes association between the study variables. Tamene (2016) argues that a study variable is a quantifiable aspect that assumes various outcomes in the subjects. The relationship between strategic resourcing and the performance of apparel and textile companies is outline in Figure 1

\section{Methodology}

This study adopted descriptive survey design. The design was chosen as the study intends to describe a population with respect to important study variables. The targeted population of the study comprised of 63 textile and apparel companies in Kenya (KAM, 2018). The unit of analysis in this study was the firm. The study targeted senior manager or operational manager as the respondent to the questionnaire.

A census study provides a true measure of the population by eliminating the sampling error. Census also provides study with a benchmark data that may be obtained for future studies and detailed information about all 
the small sub-groups within the population that is more likely to be available. For these reasons, the researcher did not do sampling but census design as it is appropriate for the study. The study used semi-structured questionnaire for primary data. Semi-structured questionnaires were chosen because they were easy to administer and analyse therefore time saving. It also provides limited effect of validity and reliability. Questionnaire was preferred because it is efficient, cheap and easy to administer in terms of monetary cost and time. The pre-test was conducted targeting managers of manufacturing textile and apparel companies in Kenya to help determine the reliability of the tool in collecting the facts. The researcher sent a Google form contain questions where the respondent filled and submitted at their own time. Respondents were accorded maximum of two weeks to answer the questionnaires and submit the instruments back. Primary data from the field was edited to eliminate errors that could have been made by the respondents. Further, the study also used Chi-square and interval-by-interval Pearson correlation to explore the relation between independent variable and dependent variable.

To ensure the ethical process was observed, intention to carry out the research was also communicated to all involved parties. There was also important in explaining the nature of the study to all respondents. After the research had been explained the nature of the study, respondents were required to fill and submit the questionnaire. In carrying out the study, the researcher sought the informed consent of respondents, and respondents were not in any way compelled to participate in giving information.

\section{Results}

\subsection{Strategic Resourcing and the performance of apparel and textile firms}

The study found most firms had sustainable financial back up plan as implied by $77.8 \%$ of respondents who strongly agreed. The mean of 4.74 and standard deviation of 0.521 implies that there was a strong harmony in the responses. Respondents also argued that the firms' budget always focused on the business expansion (agree $=58.6 \%$ and strongly agree $=17.2 \%$ ). It was further noted that the organizations studied had the skills and manpower that was needed for expansion as shown by $56.9 \%$ of those who agreed and $17.2 \%$ of those who strongly agreed. Firms also reported that they had adequate working capital (agreed $=58.6 \%$ and strongly agreed $=12.1 \%$ ) and adequate source of additional raw materials as shown by a $69.0 \%$ of those agreed and $31.0 \%$ of those who strongly agreed. On access to additional manpower over $75 \%$ of firm generally report agreement that they had access to additional manpower $(63.8 \%$ of those agreed and $12.1 \%$ of those who strongly agreed. Firms further reported that they had right technology for extra production needs (agreed $=71.4 \%$ and strongly agreed $=16.1 \%$ ), and enough organized production zone (Agreed $=69.0 \%$ and strongly agreed $=12.1 \%$ ).

\subsection{Performance of apparel and textile Manufacturing Companies}

The study further assessed performance of apparel and textile manufacturing companies using various set of indicators. The study sought to find whether the change over the period of one year for various indicators was decrease, increase or no charge. These parameters include; market share, customer retention and loyalty, repeated order/customer return, brand recognition, customer satisfaction, product stock out, defective products and employee turnover (table 4.2)

On the performance of apparel and textile manufacturing companies in Kenya, the study found that market share of most apparel and textile firms had increased as shown by a mean of 2.76 and standard deviation of 0.432 . The study found $89.3 \%$ felt the customer loyalty in their firms had increased while $79.3 \%$ reported increased repeated order/customer return. It was also noted that $86.2 \%$ firms felt that brand recognition had increased. The respondents further reported increased $(79.3 \%)$ customer satisfaction, increased $(72.4 \%)$ product stock out, average decrease in defective products and increased (65.5\%) employee turnover.

\subsection{Association between Strategic resourcing and the performance of apparel and textile firms}

The study further sought to establish association between strategic resourcing and the performance of apparel and textile companies in Kenya. This was computed using Chi-square test of association and strength of association determined using interval-by-interval Pearson correlation coefficient. The study found the relationship between strategic resourcing and the performance of apparel and textile firms had a Pearson's Chi-square $\left(\mathrm{X}^{2}\right)=169.911$. The association was found to be statistically significant at $\alpha=0.05$ (table 4.3 ).

The study also assessed the strength of association between strategic resourcing and the performance of apparel and textile firms. The study found a positive Pearson correlation of 0.903 between the relationship between strategic resourcing and the performance of apparel and textile firms. This implies that for every unit increase in strategic resource, the apparel and textile firm performance will increase by 0.903 units.

\section{Summary and Conclusions}

The study concludes that strategic positioning significantly affected the performance of manufacturing firms in Kenya. The study also concludes that strategic resourcing affected the performance of apparel and textile companies in Kenya. The study further concludes that the research and development affected the performance of 
apparel and textile companies in Kenya. Finally, the study concludes that marketing strategies significantly affect the performance of apparel and textile companies in Kenya. The study findings inform policy makers in effort to build Kenyan textile and apparel companies, and the future scholars in this subject. The findings also gives insight to players in the industry on how positioning would help them become competitive in the industry.

\section{Recommendations}

The study recommends manufacturing firms to increase their strategic positioning approaches in effort to increase the performance of apparel and textile companies in Kenya. The study found strategic resourcing which include financial back up plan, skilled work force, enough working capital, source of additional raw materials etc. significantly influenced the performance of manufacturing companies and therefore companies in manufacturing should endeavour to intensify their strategic resourcing approach.

\section{Limitations of the Study}

A number of limitations were anticipated for the current study undertaking. The targeted participants are made are representative of business organizations that operates under strict schedules. To moderate this shortcoming, email method was used in administering of questionnaires. The targeted participants could also be hesitant to provide some of the contents of the instrument. This is because business strategic position and performance constitute very sensitive information that could jeopardize the competitive position of the firm if shared irresponsibly. The researcher attached a personal commitment letter providing that the data would be responsibly handled and would not be divulged to third parties. Authorizations from Kabarak University and NACOSTI permit were provided where requested to guarantee respondents that study was purely done for academic goal of the study. The emails were also sent from the kabarak.ac.ke domain thus the email was identified with learning institution.

\section{References}

Bai, D., \& Liu, P. (2019). Research on Development Strategy of Manufacturing Industry in Pearl River Delta Based on SWOT-AHP Model.

Kenya Association of Manufacturers (2018), Manufacturing in Kenya Under the 'Big 4 Agenda' A Sector Deepdive Report. http://kam.co.ke/kam/wp-content/uploads/2018/10/KAM-Manufacturing-Deep-Dive-Report2018.pdf

KNBS (2019) economic survey. https://dc.sourceafrica.net/documents/119527-Kenya-Economic-Survey2019.html

Lii, P., \& Kuo, F. I. (2016). Innovation-oriented supply chain integration for combined competitiveness and firm performance. International Journal of Production Economics, 174, 142-155.

Luo, J. (2017). Factors affecting marketing strategies on performance of foreign owned manufacturing firms in Kenya: a case study of Erdemann gypsum limited (doctoral dissertation, MUA).

Mackelprang, A. W., Bernardes, E., Burke, G. J., \& Welter, C. (2018). Supplier innovation strategy and performance: A matter of supply chain market positioning. Decision Sciences, 49(4), 660-689.

Merozwa, G. (2015). Liquidity and Bank Performance. International Journal of Economics and Business Research, 14(3):453-462.

Noreen, S. (2015). Relationship among Strategic Positioning, Strategic Customer Relationship Management and Organization's Performance. International Journal of Management Research and Emerging Sciences, 5(1), 47-63.

Onguko, M. A., \& Ragui, M. (2014). The role of strategic positioning on products performance in the telecommunications industry in Kenya. International Journal of Science and Research, 3(10), 1309-1314.

Phillips, S. (2017). Resourcing Strategies'. The Emerald Handbook of Modern Information Management. Emerald Publishing Limited, 707-728.

Porter, M. E. (2017). Strategy: Creating and Sustaining Competitive Advantage.

Rajkumar, K. P., \& Abraham, M. (2018). Strategic positioning and sustainable competitive advantage for growth of industry. Organized by, 160.

Sulieman, A. (2015). The Effect of the Liquidity Management on Profitability in the Jordanian Commercial Banks. International Journal of Business and Management, 10(1): 62.

Valipour, H., Birjandi, H., \& Honarbakhsh, S. (2012). The effects of cost leadership strategy and product differentiation strategy on the performance of firms. Journal of asian Business strategy, 2(1), 14. 
Independent variable

Strategic resourcing

- Strategic financial resources Strategic expertise and capabilities
Dependent variable

\section{Performance}

- Employees turn over

- Market share

- Repeated order/Customer return

- Defective products

- Product stock out

Table 4. 1: Strategic Resourcing and the performance of apparel and textile firms

\section{Statements}

The firm has sustainable financial back up plan

The firms budget always focuses on the business expansion

The organization has got the skills and manpower that is needed for expansion

The firm has maintained adequate work capital

The firm has adequate source of additional raw materials

The firms has access to additional manpower

The firm right technology for extra production needs

The firm has enough organized production zone
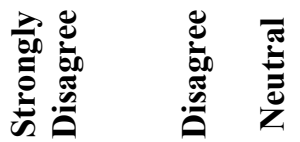

$\underbrace{0.0}_{0}$

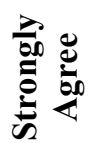

总 क

\section{$\mathrm{n}$}

(\%)

$\mathrm{n}$

0

$(0.0)$

(\%)

$\mathrm{n}$

$\mathrm{n}$

$\mathrm{n}$

(0.0)

$(0.0) \quad(3.4)$

2

(\%)

(\%)

0

$(0.0)$

(3.4)

(3.7)

10

42

$4.74 \quad 0.521$

(0.0)

(6.9)

(20.7)

34

10

$4.29 \quad 0.562$

(58.6)

(17.2)

10

(19.0)

(56.9)

(17.2)

$4.48 \quad 0.504$

$\begin{array}{ccc}2 & 15 & 34 \\ (3.4) & (25.9) & (58.6)\end{array}$

7

$4.24 \quad 0.572$

$1 \quad 2$

(1.7) (3.4)

4

$(58.6)$

(12.1)

(6.9)

(69.0)

11

$\begin{array}{cc}0 & 5 \\ (0.0) & (8.6)\end{array}$

9
$(15.5)$

37

(19.0)

$4.31 \quad 0.467$

$(0.0) \quad(8.6) \quad(15.5) \quad(63.8)$

7
$(12.1)$

$\begin{array}{ll}4.31 & 0.537\end{array}$

$0(0.0) \quad(3.6)$
0

(8.9)

(71.4)

9

0
$(0.0)$

4

7

40

(16.1)

$4.31 \quad 0.537$

(12.1)

(69.0)

(12.1)

$4.17 \quad 0.534$

Table 4. 2: Performance of apparel and textile Manufacturing Companies

\section{Indicators}

Market share

Customer retention and loyalty

Repeated order/Customer return

Brand recognition

Customer satisfaction

Product stock out

Defective products

Employee turn over

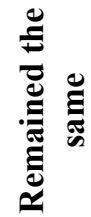

$\mathrm{n}(\%)$

O(0.0)

$0(0.0)$

$0(0.0)$

0(0.0)

0(0.0)

$0(0.0)$

32(55.2)

$0(0.0)$

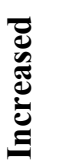

Е

n $(\%)$

n (\%)

$14(24.1)$

44(75.9)

2.76

.432

6(10.7)

50(89.3)

2.89

.312

.409

.348

2.551

.451

.502

.479 
Table 4. 3: Association between Strategic resourcing and the performance of apparel and textile firms Chi-Square Tests

\begin{tabular}{|c|c|c|c|}
\hline & Value & df & Asymp. Sig. (2-sided) \\
\hline Pearson Chi-Square & $169.911^{\mathrm{a}}$ & 56 & .000 \\
\hline Likelihood Ratio & 141.126 & 56 & .000 \\
\hline Linear-by-Linear Association & 44.077 & 1 & .000 \\
\hline $\mathrm{N}$ of Valid Cases & 55 & & \\
\hline
\end{tabular}

a. 72 cells $(100.0 \%)$ have expected count less than 5 . The minimum expected count is .02 . 